The Geneva Papers on Risk and Insurance, 15 (No. 57, October 1990), 402-406

\title{
The Ecu as a Currency for Financial Transactions: An Overview*
}

\author{
by Sir George Blunden**
}

I was honoured to be invited to give the first talk in your day of discussion on the theme of the Ecu and insurance. Honoured, but a little surprised, since I cannot claim to be an expert on the insurance market and I am certainly not expert on many technical details of the Ecu. What I can say positively is that the Bank of England has for a long time been keen to encourage the use of the Ecu. So I am happy to be able to extend this encouragement to the insurance market. Whether what I say over the next half hour really goes much further than that, I will leave it to you to judge.

The fact that we are gathered together in the Lloyd's building today is, of course, testimony to the increasing interest being shown in the Ecu. Its use has certainly "taken off" in its first ten years of existence, but I confess I had not altogether grasped how far its orbit extended until recently, when I read in the papers of your conference in Geneva earlier this year, that it is now used to denominate the insurance contracts for the European Space Agency's operations!

By way of a brief introduction to the rest of your day, I would like to begin by looking at how and why the Ecu has become established, in such a relatively short space of time, as the numeraire for an increasingly wide range of transactions and financial instruments. I will then move on, keeping, I hope, out of orbit with my feet firmly on the ground, to discuss the future development of the Ecu.

The origin of the Ecu was as a replacement for the European Unit of Account, which used to be the accounting unit for the budget of the European Community. The Ecu's definition as a basket of set amounts of European currencies was laid down in a Council of Ministers' Regulation of 1978 and from this it emerged as an instrument within the European Community. The Ecus created within the private sector follow this definition and are created, as and when desired, simply by bundling together the appropriate amounts of component currencies. The resulting so-called private Ecu is the subject of your discussions today.

* Talk as delivered to the Geneva Association / City University Business School Seminar on "The Ecu and Insurance" at Lloyd's of London on 15th November 1989.

** Deputy Governor, Bank of England, at the date of this talk. 
There is, of course, also a notional "official" Ecu whose use is tightly circumscribed. It is primarily a book-keeping device used in settlements between central banks within the EMS and is "created" by each central bank swapping $20 \%$ of its gold and dollar holdings with the European Monetary Co-operation Fund. The official Ecu can only be used between EC central banks and certain designated other holders and in practice is used primarily to repay debts between central banks which arise as a result of intervention to support ERM exchange rate parities. Besides these official Ecus, some central banks are increasingly holding private Ecus in their reserves, but it is important to recognise that these are distilict from and additional to their holdings of official Ecus with the European Monetary Cooperation Fund. Thus when the Bank of England or other central banks intervene in the foreign exchange market in Ecus, as they have done recently, the Ecus which are used are of the private commercial variety rather than the official Ecus used within the EMS. Intervention in Ecu can, incidentally, have considerable advantages over intervention in individual national currencies because it results in less disturbance to relationships among the European Community currencies.

The Ecu has recently passed an important milestone in its development. This September saw the second five-yearly review of the Ecu's composition. The previous reweighting was in September 1984 when the Greek drachma was included. The major change this time was the inclusion of the Spanish peseta and Portuguese escudo. The operation was potentially more of a risk than in 1984, however, for Ecu markets are larger now than they were five years ago and the inclusion of the peseta in particular entailed a significant shift in the Ecu's composition.

The reweighting operation was nonetheless a success. The reduction in the weights of low interest currencies back towards their 1984 levels and the addition of the two relatively high interest currencies was achieved with minimal disruption to the Ecu market. The conduct of the reweighting operation in a way least likely to cause market anxiety was due in part to pressure from individual member states (and in this the Bank of England played a leading part) as well as from the major players in the Ecu markets, with vital support from the European Commission. Largely because of this pressure, as you no doubt know, the Council of Ministers announced in June, three months ahead of the recomposition, the currency weights that would be used on 21 st September to calculate the new currency amounts. This enabled the markets to adjust smoothly in advance of the effect of the recomposition.

With the recomposition behind it, the Ecu would now appear to be in a strong position to build on the achievements of the last ten years. These are by no means unimpressive and the evidence shows that the Ecu is now well established in international financial markets. Figures from last year indicate that it accounted for around two and a half per cent of banks' outstanding international lending and for four per cent of the stock of international bonds. Ecu business is admittedly still primarily interbank: nevertheless in the field of commercial invoicing and settlement the Ecu accounted for around one per cent of Community transactions. These figures suggest that although the Ecu is not as yet a major international currency it is nonetheless playing a useful, if specialised, role.

One of the attractions of the Ecu is that it may act as an alternative to the dollar when people want a currency unit which is less volatile than any one of its component currencies. However, this motivation for its use may decline if, as there are grounds to expect, Euro- 
pean exchange rates become increasingly stable. Another of its attractions is that both investors and borrowers can seek to take advantage of the persistently high interest rate differentials between the Ecu's component currencies; thus borrowers from high interest countries may regard borrowing in Ecus as relatively cheap while investors from low interest countries may regard it as a profitable investment opportunity. However, much depends here on the extent to which potential borrowers or investors are prepared to act on the expectation that these perceived interest rate differentials will not be offset by exchange rate movements.

A recognition of the development of the Ecu market to date and a pointer to future growth in its use occured recently when, on 26 October, the London International Financial Futures Exchange launched a three-month interest rate Ecu future contract. This enables Ecu depositors and lenders and those involved in the swap and forward rate agreement markets to hedge against interest rate movements and should prove an important instrument that will deepen the Ecu market and further promote its use. Though the first of its kind, the Ecu interest rate future is a well-researched move by LIFFE which is strongly supported by the Ecu Bankers' Association. It will also act as a useful supplement to our Ecu Treasury Bill programme. The contract has already made a satisfactory start and with the novel provision of three market-makers easing the problem of the relative illiquidity of short-term Ecu markets it should certainly help to consolidate London's position as the leading Ecu market centre.

Opinion polls conducted by the Ecu Banking Association have, I believe, provided further reasons to expect continued Ecu growth by showing that latent demand is strong. Some argue that this demand should somehow be released through the provision of more information on the Ecu's potential. If the market itself feels that Ecu advertising would be profitable - and there may well be a good Ecu slogan out there somewhere (perhaps something along the lines of 'keeping all one's Ecus in one basket'?) then all well and good; but I am not convinced that Ecu advertising by the authorities would help the Ecu's development.

More generally, I do not share the opinion of those who say that the Ecu has reached a point where it can develop no further without official action to support and nurture it. The evidence to date, after all, points to the contrary and the removal of remaining exchange controls in Europe and the increasing integration of European markets should serve to bring that latent demand into the open.

That is not to say, however, that there is no role at all for the authorities in encouraging the use of the Ecu. But official encouragement should always be closely attuned to market demand and should seek to remove obstacles that prevent the Ecu from competing with individual national currencies on equal terms. Although to some extent greater substitution and competition between European currencies, including the Ecu, is already happening and although, as I have said, the Ecu has a certain undeniable commercial attraction of its own, it has nonetheless suffered from some handicaps vis-à-vis its competitors. It is in alleviating these handicaps that there may be room for some official action.

In particular, because the Ecu is still adolescent and has no natural home base, its markets have tended to be rather illiquid, particularly for the shorter term instruments. It was partly to help the development of the Ecu by improving the liquidity of the Ecu money 
markets, and partly to provide added flexibility in the management of the UK's reserves, that in August 1988 the UK authorities launched a programme of issues by monthly tenders of UK Government Ecu Treasury Bills (in other words, short-term paper not only denominated in, but also payable in, Ecus).

The first tender took place in October 1988 and in its first twelve months the programme has been a great success. Turnover in the Bills has averaged over 4 bn Ecu a month in the first three quarters of 1989 and reached 8 bn Ecu in October this year, and each monthly tender has been substantially oversubscribed. As a result of the strong demand for the Bills, the outstanding issue has already grown to 2.7 bn Ecu and will over the next few months rise to 3 bn Ecu. In the tender yesterday, the offer was 2.8 times oversubscribed and was sold at an average of some twenty basis points under prevailing Ecu LIBID rates.

Although the Bank of England does not receive detailed reports on all the final holders of these Ecu Treasury Bills, contracts with the listed market makers in them and with other market participants suggest that just over three-quarters of the total bills outstanding are held in hands other than the market makers themselves. These final holders include central banks, with interest here by no means confined to European central banks, and also international institutions, corporations and even private individuals.

Given this auspicious start, it is likely that the programme will continue to grow over time in line with perceived demand. I warmly welcome the fact that other member states have now also started to issue a greater volume of Ecu denominated debt.

A further handicap to the Ecu in its early years, once again due in part to the lack of a domestic base, was that the Ecu markets lacked an efficient clearing system. This was remedied to a significant extent in 1986 when commercial banks set up the Private Ecu Clearing and Settlement System, using the BIS as its agent. This has worked well since then but now, with the expansion of the markets, participants are considering how to enlarge membership of the clearing system while at the same time ensuring that it retains the efficiency and integrity which are essential for any national or international payment system. There may well be a limited role for the authorities here in assisting the market in building a system which is reliable, efficient, prudently managed and flexible enough to adapt to market growth.

So what will be the future of the Ecu? It is at this point that questions about the Ecu become entwined in the arguments over the wider question of monetary integration in Europe. The Ecu has perhaps already become more a currency unit than simply a basket of currencies dependent solely on its constituent elements. However, it remains no more than a currency unit because there is no central bank with a capacity to issue Ecu to the public.

There are indeed those who envisage the Ecu becoming a currency issued by a European central bank. It would then become a fully-fledged currency, issued and used in parallel with existing currencies. Indeed, some go further and argue that the authorities should seek to force the pace of its development by granting it favourable status over national currencies. In time, the argument runs, the Ecu could displace national currencies and could eventually become the single currency within what would then be a monetary union. 
Although there are of course some attractions in gradually introducing a single currency in parallel in this way, I confess that the whole scheme seems to me to be far too ambitious. Left to its own devices I cannot see how the Ecu would displace national currencies other than perhaps in certain international transactions. Without any particular attractions to encourage people to use a parallel currency they are likely to persist in using the national currency with which they are already familiar. Compulsory measures introduced by the authorities to increase its use would therefore be necessary but would surely be unacceptable.

I do not, however, wish to say that the Ecu will never become the single European currency. But until the European Community decides that it is ready for a single currency, we surely cannot decide on its name and value. The Ecu would, of course, be a natural candidate and it might well be chosen for political and symbolic reasons. Indeed, this was precisely the point made in the Delors Report earlier this year on economic and monetary union in Europe. That said, we are some way from economic and monetary union at present. The European Council agreed at its Madrid meeting to launch the first stage of economic and monetary union on 1 July 1990. However, as stated in the Government's paper on this subject presented at the meeting of European Community Finance Ministers this week, this first stage will be lengthy and may set in motion changes which result in a reconsideration of the most appropriate means of achieving the objectives of economic and monetary union. This paper attracted approving comments from a number of other member countries. Thus there seems little point in trying to change the role and nature of the Ecu now.

The existing Ecu is, then, hardly an embryonic common currency and I see no reason for large-scale intervention by the authorities to develop either the private or the official Ecu in the short to medium term, although there is equally no reason why the authorities should not seek to remove any artificial barriers which are placed in the way of the development of the Ecu for commercial purposes and, as with our own Ecu Treasury bill programme, to assist this development by introducing instruments for which a natural market demand exists. Moreover, the debate over whether the Ecu should remain a currency unit or should become a fully-fledged currency issued by a central bank is not of itself crucial to the use of the Ecu in the private sector today. The simple fact is that for the vast majority of transactions the Ecu can already be used if people so wish. But, quite understandably, for many transactions people do not wish to do this.

In the longer term it may well be that Europe will have a common currency called the Ecu but, as I have suggested, that would be something quite different from the Ecu we have today. There may well in the meantime be pressure to force the pace of European economic and monetary union by favouring the Ecu over national currencies and developing it into a parallel currency. But without lasting convergence of economic performance any such moves are unlikely to succeed. More probable, therefore, is that as a European Community moves towards greater economic and monetary integration, there will be increasing substitutability between European currencies, including the Ecu. The continued success of the Ecu will then - as it does now - depend on its meeting a specific market demand.

I hope that you are successful today in identifying specific market demands for the use of the Ecu in insurance transactions. Indeed my theme has been that the pace of the Ecu's development depends essentially on pressure from markets such as yours, rather than on intervention by the authorities. 